\title{
ONLINE PURCHASE DECISION MODEL FROM A TRUST AND EASE OF USE PERSPECTIVE IN THE ONLINE MARKETPLACE (CASE STUDY AT TOKOPEDIA.COM)
}

\author{
Raihan Fajri Ramadhan ${ }^{1}$, Rita Komaladewi², Asep Mulyana ${ }^{3}$ \\ 1,2,3 Magister Management Science, Faculty of Economics and Business, Universitas Padjadjaran, Bandung, Indonesia \\ Correspondence Author: raihan.fajri95@gmail.com
}

\begin{abstract}
This study aims to describe and examine the impact of Trust and Ease of Use through E-Commerce in Online Purchase Decision at Marketplace Online. The methodology design used in this research is quantitative research with a survey method, for an analysis tool used is multiple linear regression. The method used to attract the sample is non-probability in the form of purposive sampling with the main criteria of the sample that is Tokopedia.com users who have made transactions at least 1 time. The size of respondents used as many as 100 respondents. The results of the study found that there is a positive and significant result of the trust and ease of use variables on online purchasing decisions both partial and simultaneous. This can be explained that the main factors that consumers consider before conducting online purchasing activities are whether they trust the sites that provide these online services and trust the online sellers on the website to encourage and build long-term relationships with consumers. Second is the impact of the ease of use on purchasing decisions, which can be explained by the ease of use perceived by Tokopedia users will tend to provide a sense of comfort and ease that affects consumers' online purchasing decisions. Thus, the recommendation for Tokopedia.com is to put more concern on updating the user experience to make it more manageable for all users to remain to use Tokopedia.com. and to strengthen payment systems and complaint handling for both consumers and sellers.
\end{abstract}

Keywords: Trust, Ease of Use, Online Purchase Decision

\section{Introduction}

The development of technology and information in the world especially the Internet is experiencing exceeding development. This makes the Internet has become a basic need for most people in addition to food, clothing, and shelter. There are at least six reasons why Internet technology is so popular. The six reasons are that the Internet has connectivity and broad reach; reduce communication costs; lower transaction costs; can reduce agency costs; interactive, flexible and easy; and can distribute knowledge quickly (Laudon, 2010).

In Indonesia alone, the Internet has begun to be developed since 1990. Until now, Internet users in Indonesia have reached 197.7 million. (APJIII, 2020) Where this shows that internet users have experienced significant growth and impact with the growth of the technology sector and information per year. not only increased Internet users in Indonesia but also trading activities have begun to undergo development. Many business people are starting to use the Internet to conduct promotions and trade, this new business in the digital world is called E-Commerce. the emergence of E-commerce, a pattern in shopping, especially internet users began to change. Without having to go directly to shopping stores, simply by accessing the providing sites or e-commerce, online consumers can already buy a product online with minimum effort.

As a means of marketing transaction that is still relatively new, e-commerce contains more uncertainty and risk compared to conventional transactions. This has become a consideration for consumers to make purchases online. Moreover, the first thing that is considered when making online purchases through e-commerce is trust. Trust becomes significant things in e-commerce (Gaurav Bansal, Zahedi, \& Gefen, 2016), especially in other online activities (Schlichter \& Rose, 2013). In the literature that discusses services, the key to increasing customer's trust is with an impact of reliable service and the importance of the credibility of a brand which is based on the role of trust (Berry, 2000). Pavlou and Geffen (2002), investigated several factors that influence transactions via the internet, trust factors become a key factor. Only customers who have high trust and courage will do transactions through internet media. In addition to trust, the next consideration for online shoppers is ease of use. Fusilier and Durlabhji (2005), found that there are factors that affect the ease of use, which is experiencing the ease of using technology to carry out the desired activities thus interact with E-Commerce technology does not require a large effort. Davis (1989) ease is defined as the belief in ease of use, which is the degree to which the user believes that the technology or system can be used easily and free from problems. The intensity of use and interaction between users and the system can also indicate the ease of use

Tokopedia.com is an online marketplace that allows individuals and business owners in Indonesia to open and manage their online stores easily and free of charge while providing a safe and comfortable online trading experience. By allowing users to be able to choose a variety of products available on tokopedia.com online without worrying about fraud because Tokopedia offers a secure payment system that nurtures a sense of trust in users. Also as a form of e-commerce, tokopedia.com presents a user-friendly website so that new users can use the website or application easily so that users perceive using tokopedia.com is very easy and does not need more effort to understand its features. the question that can be found for the phenomenon that is, how to describe trust, ease of use and online purchasing decisions at Tokopedia.com. And how is the importance of trust and simplicity in using ecommerce in online purchasing decisions on Tokopedia.com both partially and simultaneously? 


\section{Literature Review}

\section{Technology Acceptance Model}

The purpose of this theory is to describe the behaviors that occur in computer users. The theory was first introduced by Fred Davis in 1986. Technology Acceptance Model (TAM) is one of the theories about the use of information technology systems that are considered very influential and is generally used to explain the individual acceptance of the use of information technology systems. TAM is a model developed from the previous model called TRA (Theory of Reasoned Action). The main purpose of TAM theory is to explain a basic step in the emergence of an external factor in internal beliefs, attitudes, and interests. There are 5 constructs in TAM which are: 1) Perceived ease of use (perceived ease of use), means the extent to which someone believes the use of technology will be free from effort. 2) Perception of usefulness (perceived usefulness), means the extent to which someone believes in the use of technology will improve performance. 3) Attitudes towards the use of technology (attitude toward using), are interpreted as evaluating the user in his interest in using technology. 4) behavior (behavioral intention), interpreted as a person's interest in performing certain behaviors. 5) Behavior can be measured by the amount of time that has been used in interacting with the technology and the frequency of use of the technology.

\section{Trust}

Trust is the belief of one party regarding the intentions and behavior of the other party. Thus consumer confidence is defined as consumer expectations that service providers can be trusted or relied upon to fulfill their promises (Siagan and Cahyono, 2014). Ba and Pavlou (2002) define trust as an assessment of a person's relationship with another person who will carry out certain transactions according to the expectations of his or her trust in an environment full of uncertainty. Research conducted by Pavlou and Geffen (2002), states of several factors affecting transactions via the internet, trust factors are a key factor. Only customers who have the trust and dare to make transactions through internet media. Mukherjee and Nath (2003), found that consumer commitment in using e-commerce is directly related to shared values namely ethics, security, and privacy and trust. Aubert and Kelsey's (2000) research uses four variables, namely ability, benevolence, integrity, and propensity to trust that influence the trust of e-commerce customers in building purchase interest. Research conducted by Chen \& Dhillon (2003) explains that forming consumer trust is very important to do by marketing, both from conventional marketers, and e-commerce.

\section{H1: Trust has a positive impact on online purchase decisions.}

\section{Ease of Use}

Ease can be interpreted as a level where someone believes that using a system can be used easily without much effort (Davis, 1989). The ease of use refers to the user's perception of the process leading to the outcome of an online transaction, and convenience is how easy it is to use the internet as a means of buying and selling online (Monsuwe et al., 2004). Adams, R. Ryan Nelson, and Peter A. Todd (1992) state that the intensity of use and interaction between users with the system can also show the ease of use. The more commonly used system shows that technology is better known, easier to operate, and easier to use by its users. Trivedi and Yadav (2018) in their research results explained that if consumers are aware of the benefits of technology and can use it easily, the purchase intention from customers can be increased. So it can be seen that ease of use has an influence on online purchasing decisions in the online Marketplace.

\section{H2: Ease of use has a positive impact on online purchase decisions.}

\section{Online Purchase Decision}

Decision is the choice of two or more choices (Schiffman \& Kanuk, 2000). The decision-making process is used in the completion of special purchases that are special, according to the needs of consumers. Purchasing decisions are the stages of the decision process where consumers purchasing a product (Kotler and Armstrong, 2004). Kotler and Armstrong (2004) state that there are five stages in the process of making purchasing decisions, namely: 1) Need recognition, 2) Information search, 3) Evaluation of various alternatives, 4) Buying decision, and 5) Postpurchase behavior. As technology develops, the use of the internet, both from various media such as computers, and smartphones make it easy for consumers to obtain knowledge and information about what they will decide to make a purchase (Gehrt et al, 2012; Taylor, 2016). Where the results of the study agree with the statements of Kotler and Armstrong (2004), whilst making purchasing decisions, information search is needed in the process. Fuller (2009) concluded in his research that there is an integration between trust and TAM, especially ease of use in explaining consumer intentions, before finally becoming a purchasing decision. Ahn (2014) suggested that there is a relationship between TAM and trust in consumer purchase intentions, so that in e-commerce, the more trust and ease that can be given to consumers, the more consumers decide to make a purchase.

\section{H3: there is a positive impact between trust and ease of use on online purchasing decisions}

\section{Methods}

This research is a quantitative study using an online survey method by examining whether there is a relationship between the independent variable which is trust, and ease of use, and the dependent variable, online purchasing decisions. The data used for this research are primary in the form of an online questionnaire distributed to several samples. The sampling technique uses a purposive sampling method with the main criteria of the sample is Tokopedia users who have been made a purchase or transaction at least 
once. Because the exact number of the population is unknown, the determination of the sample used uses the Slovin Method. Based on the calculation results obtained sample size taken from a population of 100 respondents.

The data analysis method uses 2 approaches, the first is using a descriptive method where it aims to see the tendency of respondents' evaluation of the questionnaire given to respondents. The second is to use quantitative methods with multiple linear regression analysis tools and hypothesis testing by conducting t-test (partial), F-test (simultaneous), and Coefficient of Determination Test.

\section{Results And Discussion}

\begin{tabular}{|c|c|c|c|}
\hline Profile & Parameter & Total & $\%$ \\
\hline \multirow{2}{*}{ Gender } & Male & 36 & $36 \%$ \\
\hline & Female & 64 & $64 \%$ \\
\hline \multirow[t]{5}{*}{ Age } & $<19$ year & 3 & $3 \%$ \\
\hline & 20-29 year & 69 & $69 \%$ \\
\hline & 30-39 year & 21 & $21 \%$ \\
\hline & $>40$ year & 7 & $7 \%$ \\
\hline & $<2$ hours & 9 & $9 \%$ \\
\hline \multirow[t]{2}{*}{ Time Spend in using internet } & 3-4 hours & 68 & $68 \%$ \\
\hline & $>5$ hours & 23 & $23 \%$ \\
\hline \multirow{4}{*}{$\begin{array}{l}\text { Shopping frequency in last } 3 \\
\text { month }\end{array}$} & $<2$ time & 48 & $48 \%$ \\
\hline & 3-4 times & 39 & $39 \%$ \\
\hline & $>5$ times & 13 & $13 \%$ \\
\hline & Fashion & 44 & $44 \%$ \\
\hline \multirow{6}{*}{ Type of goods } & Handphone & 8 & $8 \%$ \\
\hline & Cosmetic & 18 & $18 \%$ \\
\hline & Otomotif & 3 & $3 \%$ \\
\hline & Household Goods & 7 & $7 \%$ \\
\hline & Laptop & 3 & $3 \%$ \\
\hline & Electronic & 7 & $7 \%$ \\
\hline \multirow{4}{*}{ Type of Gadget } & Health & 10 & $10 \%$ \\
\hline & Desktop & 32 & $32 \%$ \\
\hline & Handphone & 68 & $68 \%$ \\
\hline & Total & 100 & 100.0 \\
\hline
\end{tabular}

\footnotetext{
Source: Research result (2018)

Based on Table 1 regarding the characteristics of respondents, the results of the first descriptive analysis that can be concluded that Tokopedia users based on gender are dominated by women which are $64 \%$ of all respondents. This shows that Tokopedia users especially women, are more often to use the Tokopedia website for shopping, or just looking for information compared to men. Whereas from the age group category, most of the respondents appear from the age group of 20-29 years, which are 69 respondents. this can be assumed in that age group the respondents are in a productive period and have an income of their own. based on the amount of time spent a day using the internet, the most dominant group of respondents was in the 3-4 hour category of 68 of respondents. It can be assumed that respondents have good control in using the internet or don't have much time to use the internet for long periods. Based on the category of shopping frequency in the last 3 months, most respondents shopped in frequency $<2$ times in the last 3 months, which are 48 respondents. Furthermore, based on the type of goods purchased, fashion good is most purchased by respondents which is 44 respondents. Thus, it can be assumed that Tokopedia users buy more fashion goods than other categories of goods. Finally, the category is based on the device used. In this case, Mobile devices are more preferred used, at $68 \%$ of the total respondents. It can be assumed that Tokopedia users prefer multi-tasking devices that are easy to carry anywhere, and anytime whether doing shopping or other activities.
} 
The second descriptive result concluded that the average score of the trust variable gets a result of 3.9 by showing a range of scales in the high category, which shows the trust offered by Tokopedia is believed by respondents to be good. Ease of getting variable is results on average by 4.1 that it can be assumed the ease of use offered by Tokopedia is believed well by respondents. Meanwhile, online purchasing decision variables get an average result of 4.1 whereas online purchasing decisions made by respondents believed in a good category.

Tabel 2. t-Test

\begin{tabular}{ccccccc}
\hline & & & Coefficients $^{\mathbf{a}}$ & & \\
1 & Model & $\mathrm{B}$ & Std. Error & Beta & $\mathrm{T}$ & Sig \\
& (Constant) & 6.602 & 3.035 & & 2.175 & .032 \\
& $\mathrm{X} 1$ & .926 & .195 & .378 & 4.753 & .000 \\
$\mathrm{X} 2$ & .946 & .151 & .498 & 6.268 & .000 \\
\hline
\end{tabular}

Source: Research result (2018)

The statistical t-test shows that how far the impact of one independent variable individually in explaining the variation of the dependent variable (Ghozali, 2011). This statistical t-test was carried out to test $\mathrm{H} 1$ and $\mathrm{H} 2$ in this study.

Based on table 2 above, it can be seen that the level of trust has a significance value of 0,000 and the regression coefficient has a positive value of 0.378 . Based on these results, $\mathrm{H} 1$ can be accepted. Furthermore, the ease of use in the above table shows a significant level of 0,000 and a positive regression coefficient of 0.498 . Based on these results, $\mathrm{H} 2$ can be accepted.

Tabel 3. F Test

\begin{tabular}{|c|c|c|c|c|c|c|}
\hline \multicolumn{7}{|c|}{ ANOVA $^{\mathrm{a}}$} \\
\hline & Model & Sum of Squares & $\mathrm{df}$ & Mean Square & $\mathrm{F}$ & Sig. \\
\hline 1 & Regression & 1349.069 & 2 & 674.534 & 81.161 & $.000^{\mathrm{b}}$ \\
\hline & Residual & 806.171 & 97 & 8.311 & & \\
\hline & Total & 2155.240 & 99 & & & \\
\hline
\end{tabular}

Source: Research result (2018)

The F test explains whether all independent variables entered in the model have a simultaneous impact on the dependent variable. If the significance of the calculated $\mathrm{F}$ is less than 0.05 , then Ho is rejected, which means that the independent variable simultaneously impacts the dependent variable (Ghozali, 2011).

Based on table 3, it can be seen, that the simultaneous significance test results (Statistical Test F) obtained the calculated F value is 81.161 and the $\mathrm{F}$ table value is 3.09 . While the significance value of 0,000 . Because the significance value is below 0.05 or $5 \%$ and the calculated $F$ value is greater than the $F$ table value (81.161> 3.09), then $\mathrm{H} 3$ can be accepted.

Tabel 4. Coefficient of Determination Test

\begin{tabular}{|c|c|c|c|c|c|}
\hline & & & & Model Summary & \\
\hline Model & $\mathrm{R}$ & R Square & & Adjusted R Square & Std. Error of the Estimate \\
\hline 1 & $.791^{\mathrm{a}}$ & .626 & .618 & & 2.88289 \\
\hline
\end{tabular}

Source: Research result (2018)

The coefficient of determination $\left(\mathrm{R}^{2}\right)$ essentially measures how far the model in explaining the variation of the dependent variable (Goodness of fit) of a model. (Ghozali, 2011).

It can be seen in table 4, the Adjusted $\mathrm{R}^{2}$ test results are 0.618 , which means that the importance of the impacting the variable trust and ease of use in online purchasing decisions is $61.8 \%$, while the remaining $38.2 \%$ is influenced by other factors not included 
in this study. So that this can be a research gap both theoretically and empirically that can be filled by other researchers by approaching factors that are not present in this study.

\section{Conclusion}

This study aims to describe and examine the impact of trust and ease of use of E-commerce in online purchasing decisions. The findings of the research show that trust influences online purchasing decisions individually. This explains that the main thing that a buyer considers when shopping online is whether they trust sites that provide online shops service and trust the seller on the site to foster and build long-term relationships (Rousseau et al., 1998). The existence of reliance on the credibility or trust in e-commerce websites will encourage consumers to believe in the products the company offers so that consumers can determine their attitude towards the website and ultimately make a purchasing decision on the company's products (Akbar and Pervez, 2009). The results of this study are consistent with previous research conducted by Hardiawan (2013) concluding that trust impacts online purchasing decisions.

Ease of use has a positive and significant impact on the perceived ease for users of online shopping, tends to be bigger and stronger in influencing online purchasing decisions where the results of this study are also consistent with previous research conducted by Saputri (2015). Perceived ease of use is one of the considerations factors for online shoppers (Davis, et al, 1998). Ease of use is how much computer technology is relatively easy to understand and use. This is related to how buyers operate when transacting online (Todd, 1995). Based on research findings that trust and ease of use in online purchasing decisions have a significant effect on online purchasing decisions. The results of this study are consistent with previous research conducted by Ardyanto (2015), concluding that the trust and ease of use variables have a positive and significant direction for online purchasing decisions simultaneously. This strengthens the explanation that weak trust and a low level of ease of use will significantly influence the low online purchasing decisions and decreasing user interest in using the Tokopedia.com site. But on the other hand, the results of the study have been able to explain well the factors of trust and ease of use together to be a driving factor in improving online purchasing decisions on the site Tokopedia.com.

There are two the suggestion that can be given both in the field of academics and practitioners. in terms of academics, is to be able to complete one of the fields of management science, and to complete the research gap by filling the research gap that transpires by using factors not included in this study, both in terms of marketing, finance, resources human, as well as in operational terms. In terms of practitioners, especially Tokopedia, to put more concern on updating the user experience to make it more manageable for all users to remain to use Tokopedia.com and strengthen the payment systems and complaint handling for both consumers and sellers.

\section{References}

Adams, D. A., Nelson, R. R., \& Todd, P. A. (1992). Perceived usefulness, ease of use, and usage of information technology: A replication. MIS quarterly, 227-247.

Ahn, T., Ik Suh, Y., Lee, J. K., \& Pedersen, P. M. (2014). Understanding purchasing intentions in secondary sports ticket websites. International Journal of Sports Marketing and Sponsorship, 16(1), 35-49.

Akbar, M. M., \& Parvez, N. (2009). Impact of service quality, trust, and customer satisfaction on customers loyalty. ABAC Journal, 29(1).

Ardyanto, D. (2015). Pengaruh Kemudahan dan Kepercayaan Menggunakan E-commerce Terhadap Keputusan Pembelian Online (Survei Pada Konsumen Www. petersaysdenim. com). Jurnal Administrasi Bisnis, 22(1)

Aubert, B. A., dan Kelsey, B. L., (2000), The Illusion of Trust and Performance, Scientific Series of Cirano, 3: pp. 1-13.

Avinandan, M., \& Prithwiraj, N. (2003). A model of trust in online relationship banking. The International Journal of Bank Marketing, 21(1), 5-15.

Bansal, G., Zahedi, F. M., \& Gefen, D. (2016). Do context and personality matter? Trust and privacy concerns in disclosing private information online. Information \& Management, 53(1), 1-21.

Berry, L. L. (2000). Cultivating service brand equity. Journal of the Academy of Marketing Science, 28(1), 128-137.

Chen, S. C., \& Dhillon, G. S. (2003). Interpreting dimensions of consumer trust in e-commerce. Information technology and management, 4(2-3), 303-318.

Davis, F. D. (1989). Perceived usefulness, perceived ease of use, and user acceptance of information technology. MIS quarterly, 319-340.

Fuller, M. A., Serva, M. A., \& Baroudi, J. (2009). Clarifying the integration of trust and TAM in e-commerce environments: implications for systems design and management. IEEE Transactions on Engineering Management, 57(3), $380-393$.

Fusilier, M., \& Durlabhji, S. (2005). An exploration of student internet use in India: the technology acceptance model and the theory of planned behavior. Campus-Wide Information Systems, 22(4), 233-246.

Gehrt, K. C., Rajan, M. N., Shainesh, G., Czerwinski, D., \& O'Brien, M. (2012). Emergence of online shopping in India: shopping orientation segments. International Journal of Retail \& Distribution Management, 40(10), 742-758.

Ghozali, I. (2011). Aplikasi Analisis Multivariate Dengan Program IBM.

Hardiawan, A. C. (2013). Pengaruh Kepercayaan, Kemudahan, dan Kualitas Informasi Terhadap Keputusan Pembelian Secara Online (Studi kasus pada pengguna situs jual beli Online tokobagus. com).

Kotler, P., \& Armstrong, G. (2004). Principles of marketing (Vol. 10th).

Laudon, K. C., \& Laudon, J. P. 2010. Management Information Systems: Managing The Digital Firm. 
Pavlou, P. A., \& Gefen, D. (2004). Building effective online marketplaces with institution-based trust. Information systems research, 15(1), 37-59

Rousseau, D. M., Sitkin, S. B., Burt, R. S., \& Camerer, C. (1998). Not so different after all: A cross-discipline view of trust. Academy of management review, 23(3), 393-404.

Saputri, A. F. B. A. (2015). Pengaruh Keamanan, Kemudahan, Dan Risiko Kinerja Terhadap Keputusan Pembelian Secara Online Di Tokopedia. com. E-Jurnal Manajemen Universitas Negeri Yogyakarta, 2(1), 115-125.

Schlichter, B. R., \& Rose, J. (2013). Trust dynamics in a large system implementation: six theoretical propositions. European Journal of Information Systems, 22(4), 455-474.

Shen, J., \& Eder, L. (2009). Determining factors in the acceptance of social shopping websites. AMCIS 2009 Proceedings, 290.

Siagian, H., \& Cahyono, E. (2014). Analisis Website Quality, Trust Dan Loyalty Pelanggan Online Shop. Jurnal Manajemen Pemasaran, 8(2), 55-61.

Taylor, E. (2016). Mobile payment technologies in retail: a review of potential benefits and risks. International Journal of Retail \& Distribution Management, 44(2), 159-177.

Taylor, S., \& Todd, P. A. (1995). Understanding information technology usage: A test of competing models. Information systems research, 6(2), 144-176.

Trivedi, S. K., \& Yadav, M. (2018). Predicting online repurchase intentions with e-satisfaction as mediator: a study on Gen Y. VINE Journal of Information and Knowledge Management Systems, 48(3), 427-447.

y Monsuwé, T. P., Dellaert, B. G., \& De Ruyter, K. (2004). What drives consumers to shop online? A literature review. International journal of service industry management. 